\title{
Composition, structure and productivity of the herbaceous vegetation of five forest stands varying in soil moisture and nitrogen in Central Himalaya, India
}

\author{
Surendra Singh BARGALI ${ }^{*}$ (D), Pankaj AWASTHI ${ }^{1}$ (D) Kiran BARGALI $^{1}$ (D) \\ $I^{*}$ Department of Botany, Kumaun University, DSB Campus, Nainital-263001 \\ Uttarakhand, India
}

Corresponding author: surendrakiran@ rediffmail.com

\begin{abstract}
Herb layer contributes significantly to the species diversity of forest ecosystem and reacts rapidly to changes in the soil characteristics. Composition, structural parameters and productivity of the herbaceous vegetation of five forest stands in the Central Himalaya of India, situated at Nainital district of Uttarakhand, India were investigated. At each site, 1 ha plot was established and herbaceous vegetation was analysed by placing 30 random quadrats of $50 \times 50 \mathrm{~cm}$ at each site. To determine the soil moisture and soil nitrogen, soil samples were collected from each site and analysed in the laboratory. Results showed that chosen sites contrasted in terms of soil moisture, total soil nitrogen, herbaceous diversity, and biomass. In this study, 70 genera, 73 species from 31 families of herbs were recorded. Total number of herbaceous species recorded in the stands varied from 28 (Pines and Hanumangarhi) to 50 (Takula).Total individuals of all herb species were 110,114,141, 164 and 188 plants $\mathrm{m}^{-2}$ in Rusi (RU), Hanumangarhi (HG), Pines (PI), Barapatthar (BP) and Takula (TA) forest stands, respectively. Index of similarity and species turnover ranged from 34.48 to 62.50 and 0.31 to 0.54 respectively. Herb density, diversity and biomass showed positive correlation with soil moisture and soil nitrogen. These findings suggested that the soil moisture and nitrogen enhanced the herbaceous diversity by ameliorating soil conditions. Herb species such as Bidens pilosa, Commelina benghalensis, Erigeron kavinskianus, Eupatorium adenophorum, Micromeria biflora, Oplismenus compositus, Oxalis corniculata, Strobilanthes angustifrons, Viola canescens, Vitis himalayana were most benefitted species because they were present across all the forest stands in high density where as herb species like Ajuga bracteosa, Anemone vitifolia, Arisaema tortuosum, Cassia occidentalis, Craniotome furcata, Dioscorea bupleuroides, Lepidagathis cristata, Sigesbeckia orientalis, Veronica beccabunga and Vicia villosa were the most affected species because they were recorded from among one of the forest stand and they are present in very low density. This study also demonstrated a straight relationship between herbaceous diversity and biomass indicating the significance of species diversity for ample generation of biomass in forest ecosystem.
\end{abstract}

Keywords: Herbaceous vegetation; productivity; soil moisture; total soil nitrogen; Central Himalaya.

\section{Introduction}

Among all kinds of vegetation types, herb layer has a pivotal role in maintaining the ecosystem equilibrium because it is mostly present in highest numbers comprising different kinds of genera and species (Gilliam, 2007; Jhariya et al. 2013; Parihaar et al. 2014; Khan et al. 2020a). This layer is also responsible for approximately $12 \%$ of the Gross Photosynthetic Production (GPP) of a forest ecosystem (Bargali and Bargali, 2000; Muller, 2003). In the forest ecosystem, the herb layer not only determines the spatio-temporal distribution but also affect dynamics of woody seedlings through regeneration. The herbaceous layer also regulates the recruitment of woody plants (Maguire and Forman, 1983) directly through competition for nutrients, light, water and indirectly through the addition of macro and micro 
nutrients (San Jose and Farinas, 1991). The fibrous root system of herbs particularly grass is beneficial in binding soil particles and maintaining soil structure, thereby substantially reducing soil erosion and water loss (Sagar et al. 2008). The herbaceous vegetation influence nutrient cycling, primary production, energy flow in the forest ecosystems (Das et al. 2008), provide forage for domestic and wild animals, exhibit attraction for many butterflies due to high richness of nectar-bearing flowers (van Swaay, 2002) and provide shelter for microbial communities (Singh et al. 2006). Therefore, the interaction between these strata promotes the structural organization and number of niches (ecosystem complexity) and finally makes the system stable.

The role of herbaceous vegetation in terms of biomass production and nutrient cycling is not significantly appreciable, however, their role in ecosystem dynamics cannot be ignored (Bargali et al. 2015a Khan et al. 2020b). Their floristic role also transcends their varied ecological importance. Species diversity that is defined by the spatio-temporal alteration in species composition and their distribution (Gillet et al. 1999), govern stability and vulnerability of forest ecosystems, understanding the composition, distribution, and diversity of herbaceous vegetation is basic to the understanding of dynamics of the forest ecosystem. Though plant species diversity is affected by a variety of abiotic and biotic factors, herbaceous vegetation of any forest ecosystem is generally most affected by edaphic factors, climatic variables and livestock grazing which in return affect regeneration of trees and shrubs, resource availability and overall scenario of forest ecosystem in that region (Bushing and Brokaw, 2002; Schnitzer and Carson, 2001; Bargali et al. 2014 and $2015 \mathrm{a}$ and b).

The rates of species gain or loss in the community are affected by disturbances such as physical resources, anthropogenic agencies, species interactions and propagules availability (Karki et al. 2016). Abiotic factors that have been considered many times for research purposes were soil moisture, nitrogen availability or related variables such as the water table. Plants utilize water for photosynthesis or respiration, and inadequate supply of water loses cell turgidity which leads to wilting and eventual death of plant. Water is a vital part of plant health that is why it has been chosen so many times in studies. Understanding the effects of change in soil moisture and total soil nitrogen on herbaceous vegetation will lead us to an improved knowledge of plant ecology. This study is an attempt to understand composition, structure and biomass production of herb layer in five forest stand of Central Himalaya in relation to soil moisture and nitrogen. The purpose of the present study was to describe the impacts of varying levels of soil moisture and nitrogen on species composition, phytosociological characters and biomass of the herbaceous vegetation in forest stands of Central Himalaya, India.

\section{Materials and methods}

\section{Study area}

This study was conducted in the Nainital Forest Division of Nainital district in Uttarakhand state, Central Himalaya, India. After conducting frequent survey in the region, five sites between $29^{\circ} 21^{\prime} 51^{\prime \prime}-$ $29^{\circ} 23^{\prime} 21^{\prime \prime} \mathrm{N}$ latitude and $79^{\circ} 26^{\prime} 31^{\prime \prime}-79^{\circ} 28^{\prime} 29^{\prime \prime}$ E longitude covering an altitudinal range of 1700 to 2200 $\mathrm{m}$ asl were selected (Table 1). All sites are within $5 \mathrm{~km}$ distance to each other, have similar topography, soil type, and experience similar climatic conditions and their respective vegetational scenario is given in table 2.

Table 1. Characteristics of the selected forest stands of Central Himalaya, India.

\begin{tabular}{clcccc}
\hline S. No. & \multicolumn{1}{c}{ Locality } & Latitude & Longitude & $\begin{array}{c}\text { Altitude } \\
\text { (m asl) }\end{array}$ & Aspect studied \\
\hline 1 & Rusi (RU) & $29^{\circ} 21^{\prime} 57^{\prime \prime} \mathrm{N}$ & $79^{\circ} 27^{\prime} 23^{\prime \prime} \mathrm{E}$ & 1756 & West \\
2 & Hanumangarhi (HG) & $29^{\circ} 21^{\prime} 55^{\prime \prime} \mathrm{N}$ & $79^{\circ} 27^{\prime} 32^{\prime \prime} \mathrm{E}$ & 1899 & East \\
3 & Pines (PI) & $29^{\circ} 23^{\prime} 1^{\prime \prime} \mathrm{N}$ & $79^{\circ} 28^{\prime} 29^{\prime \prime} \mathrm{E}$ & 1902 & West \\
4 & Barapatthar (BP) & $29^{\circ} 23^{\prime} 21^{\prime \prime} \mathrm{N}$ & $79^{\circ} 26^{\prime} 31^{\prime} \mathrm{E}$ & 2134 & South East \\
5 & Takula (TA) & $29^{\circ} 21^{\prime} 51^{\prime \prime} \mathrm{N}$ & $79^{\circ} 27^{\prime} 29^{\prime \prime} \mathrm{E}$ & 1798 & North east \\
\hline
\end{tabular}


Table 2. Vegetation scenario of selected forest stands

\begin{tabular}{|c|c|c|c|c|c|}
\hline \multirow{2}{*}{$\begin{array}{l}\text { S. } \\
\text { No. }\end{array}$} & \multirow{2}{*}{ Locality } & \multicolumn{3}{|c|}{$\begin{array}{l}\text { Dominating species (On the basis of IVI for tree and shrub and PV for herb) } \\
\text { (Total species number) }\end{array}$} & \multirow{2}{*}{$\begin{array}{c}\text { Total woody } \\
\text { vegetation } \\
\text { cover }\left(\mathrm{m}^{-2} \mathrm{ha}^{-1}\right)\end{array}$} \\
\hline & & Tree & Shrub & Herb & \\
\hline 1 & Rusi (RU) & $P$. roxburghii (3) & C. nepalensis (3) & E. karvinskianus (30) & 24.01 \\
\hline 2 & Hanumangarhi (HG) & C. torulosa (5) & C. nepalensis (5) & O. compositus (28) & 20.13 \\
\hline 3 & Pines (PI) & Q. leucotrichophora (4) & C. nepalensis (7) & E. karvinskianus (28) & 17.41 \\
\hline 4 & Barapatthar (BP) & Q. leucotrichophora (4) & C. nepalensis (10) & C. dactylon (35) & 29.91 \\
\hline 5 & Takula (TA) & C. torulosa $(7)$ & C. nepalensis (9) & E. karvinskianus (50) & 25.27 \\
\hline
\end{tabular}

\section{Climate}

The climate of the study area is a typical temperate type. The climate is determined by the monsoon rhythms and the year can be divided into three main seasons: winter, usually cold and relatively dry (mid-December to February or sometimes mid-March); summer, warm and dry (April to mid-June); and a rainy season, which is warm and wet (mid-June to mid- September). The period of transition occur between summer and winter and between winter and summer are autumn (October to November) and spring (February to March), respectively. The rainy season accounts for about three-fourths (3/4) of the annual rainfall. During winters, some parts of the study area receive snowfall. The Mean minimum monthly temperature ranged from $7{ }^{\circ} \mathrm{C}$ (January) to $21^{\circ} \mathrm{C}$ (August) and mean maximum monthly temperature varied from $13^{\circ} \mathrm{C}$ (January) to $30^{\circ} \mathrm{C}$ (September). Annual rainfall was $2200 \mathrm{~mm}$. Average humidity fluctuated near the saturation point during the monsoon and was lower during summer, and ranged between $36.5 \%$ (May) to $88.7 \%$ (July) (Fig.1).

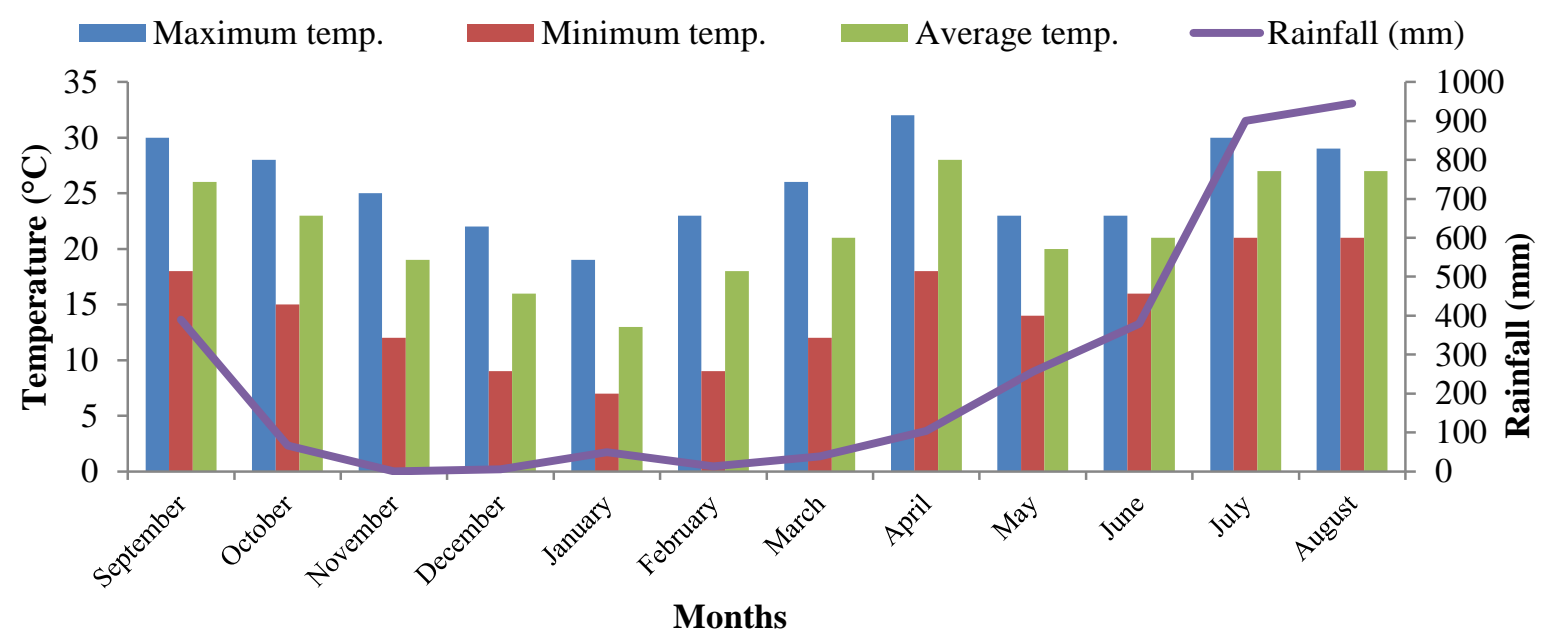

Figure 1. Meteorological data of study sites during September 2017-August 2018 (Source: ARIES, Nainital)

\section{Sampling procedure}

Five sites at five different locations were selected in five different forest stands dominated with different kinds of genera and species of trees such as Pinus roxburghii, Quercus leucotrichophora, Cedrus deodara, Cupressus torulosa etc. For the herbaceous vegetation analysis, 1 ha plot was established in that forest stand and 10 quadrats of $10 \mathrm{~m} \times 10 \mathrm{~m}$ were placed in it and in that each quadrat, three $50 \mathrm{~cm}$ x $50 \mathrm{~cm}$ size quadrats ( 5 site x 30 quadrats $=150$ quadrats) were placed randomly (Misra, 1968). The sampling was done in the month of September which is considered as a peak growth period as well as maximum availability of herb diversity and biomass production (Bargali and Bargali, 2000). The number and size of the quadrats were determined by the running mean method (Kershaw, 1973) and species area curve (Misra, 1968) method. Herb species of every quadrat were uprooted and species 
number, density, provenance value and biomass were recorded for every species separately. Total biomass for herbs was calculated by adding the aboveground and belowground biomass. Unidentified species were put between paper sheets and marked according to their quadrat number. These unidentified herb species were then brought to laboratory and with the help of experts and relevant flora, they were identified. Uprooted (Both above ground and belowground parts) herb species were packed in paper bags and oven dried at $80^{\circ} \mathrm{C}$ for $48 \mathrm{hrs}$ or till they achieve a constant weight. From each site soil samples were collected from two depths i.e. surface layer $(0-15 \mathrm{~cm})$ and sub- surface layer (15$30 \mathrm{~cm}$ ) with the help of soil corer. For soil moisture, immediate soil weight was taken at respective sites and these samples were then put into polythene zipper bags, oven dried at $80^{\circ} \mathrm{C}$ for $48 \mathrm{hrs}$ or till they completely devoid of any kind of moisture. Total soil nitrogen was determined by the micro-Kjeldahl method (Peach and Tracey, 1956).

\section{Data Analysis}

For the determination of soil moisture following formulae was used

Soil moisture $(\%)=$ Fresh weight of soil-dry weight of soil/dry weight of soil $\times 100$

Provenance value (PV) of each species was calculated by summing up their respective relative frequency (RF) and relative density (RD):

$$
\text { Provenance Value }(\mathrm{PV})=\mathrm{RF}+\mathrm{RD}
$$

The species with highest value of PV was identified as dominant and that having the second-highest value was defined as co-dominant species. $\alpha$-diversity was calculated using the Shannon-Wiener index $\left(\mathrm{H}^{\prime}\right)$.

$$
\mathrm{H}^{\prime}=-\mathrm{Pi} \log _{2} \mathrm{Pi}(\text { Shannon and Weaver, 1963) }
$$

Where,

$\mathrm{Pi}$ is the proportion of total stand basal area represented by the $\mathrm{i}^{\mathrm{st}}$ species.

The working formula given by Smith (1974) was used here as;

$$
\left.\mathrm{H}^{\prime}=3.322\left[\mathrm{Ni} / \mathrm{N} \log _{10} \mathrm{Ni} / \mathrm{N}\right)\right]
$$

Where,

$\mathrm{Ni}$ is the total density of species and $\mathrm{N}$ is the total density of all the species. The factor 3.322 was used to convert the index value to $\log _{2}$.

Species evenness (e) and $\beta$-diversity for each site was calculated using the following formulae:

$$
\begin{array}{cl}
\mathrm{e}=\mathrm{H}^{\prime} / \ln \mathrm{S} & \text { (Whittaker, 1972) } \\
\beta=\frac{\mathrm{Sc}}{\overline{\mathrm{s}}} & \text { (Whittaker, 1972) }
\end{array}
$$

Where, $\mathrm{H}^{\prime}=$ Diversity of species; $\mathrm{S}=$ Number of species, $\mathrm{pi}=$ proportion of provenance value belonging to species ' $\mathrm{i}$ ', $\mathrm{Sc}=$ total number of species, $\overline{\mathrm{S}}=$ Average number of species per sample.

Index of similarity $(\%)$ between two sites was calculated using Sorensen's index for presence/absence data as

$$
\mathrm{SI}=2 \mathrm{C} /(\mathrm{a}+\mathrm{b})
$$

Where, ' $\mathrm{C}$ ' is the number of species of species common to both sites, ' $\mathrm{a}$ ' is a number of species at site first and ' $b$ ' is the number of species at site two.

Species turnover (ST), a measure of floristic change between two selected sites, was calculated as:

$$
\mathrm{ST}=(1+\mathrm{g}) /(\mathrm{a}+\mathrm{b})
$$


Where 1 is the number of lost and $g$ is the number of species gained between two selected sites; ' $a$ ' and ' $b$ ' are the same as in equation for SI (Schoomaker and McKee, 1988).

The Statistical analysis was done by using SPSS 25.

\section{Results}

Recorded herb species in the five forest stands are presented in Table 3. Total 73 herb species from 31 families were reported from five sites covering $37.5 \mathrm{~m}^{-2}$ area. Highest family Asteraceae (16) recorded maximum number of herb species followed by Lamiaceae (7) and Poaceae and Polygonaceae with 6 species each (Table 3). Total number of herb species per site ranged from 28 (PI and HG) to 50 (TA) (Table 5) and number of unique species per site varied from 2 (PI) to 11 (BP and TA) (Table 3), while 9 species were present in all the five sites. On the basis of provenance value (PV), out of five sites, three sites (PI, RU and TA) showed same dominant and co-dominant species as Erigeron karvinskianusOxalis corniculata respectively. At site- BP Cynodon dactylon-Erigeron karvinskianus whereas at siteHG Oplismenus compositus-Cynodon dactylon were dominant and co- dominant species, respectively. Density of herbs (plant $\mathrm{m}^{-2}$ ), soil type, soil moisture and total soil nitrogen of selected studied sites are given in Table 4. Highest density of herbs was 188 plant $\mathrm{m}^{-2}$ at site-TA followed by site-BP (164 plant $\mathrm{m}^{-2}$ ) and site-PI (141 plant $\mathrm{m}^{-2}$ ) whereas the soil moisture varied between $5.56 \%(\mathrm{RU})$ to $11.43 \%(\mathrm{BP})$ in surface layer $(0-15 \mathrm{~cm})$ and $7.09 \%(\mathrm{RU})$ to $15.40 \%$ (BP) in the sub-surface layer $(15-30 \mathrm{~cm})$. Total soil nitrogen ranged from $0.20 \%$ (RU) to $0.41 \%$ (TA) (Table 4). Herb density increased with increasing soil moisture (\%) and total soil nitrogen (\%) indicating that soil fertility increased growth of herbs (Table 4). $\beta$-diversity, Shannon index, evenness and biomass per site varied from 1.46 (TA) to 2.61 (PI and HG), 4.01 (PI) to 5.09 (TA), 1.204 (PI) to 1.316 (RU) and $2.36 \mathrm{~kg} \mathrm{~m}^{-2}$ (PI) to $6.46 \mathrm{~kg} \mathrm{~m}^{-2}$ (TA), respectively (Table 5). Figure 2 showed dominance diversity curve in which bottom curve (site-TA, Erigeron karvinskianus-Oxalis corniculata community) represented the highest diversity, while the uppermost curve (site-HG, Oplismenus compositus-Cynodon dactylon community) represented the lowest diversity.

Highest index of similarity was recorded between sites RU-TA (62.50\%) followed by between sites PITA $(61.33 \%)$. Among all the selected sites, only two combinations of sites has similarity index below $50 \%$ i.e. RU-BP (46.15\%) and RU-PI (34.48\%) (Table 6). Species turnover ranged from 0.31 to 0.54 with highest turnover between sites RU-BP (0.31) and lowest was between sites RU-PI (0.54) (Table 7). Across the sites, herbs showed all kinds of distribution pattern i.e. regular, random and contagious. Maximum number of herb species showed contagious distribution pattern followed by random and regular distribution (Fig. 3).

One-way ANOVA showed significant $(p=\leq 0.001)$ changes in soil moisture $(\%)$ and total soil nitrogen with respect to selected forest stands (Table 8). Soil moisture and total soil nitrogen significantly affected species number and diversity. Shannon's index and biomass, species number and herb density are significantly related to each other (Fig. 4). Shannon's index and biomass of herbs showed nonsignificant relationship with both linear and non-linear models used in the analysis but linear model exhibited a better fit to the data compared to non-linear models (Table 9).

Table 3. Provenance value (PV) of herbaceous species at five sites in forests of Central Himalaya, India.

\begin{tabular}{|c|c|c|c|c|c|c|}
\hline Herb species & Family & $\mathbf{R U}$ & HG & PI & BP & TA \\
\hline Achyranthes bidentata Blume & Amaranthaceae & 0.00 & 5.65 & 9.33 & 0.00 & 3.99 \\
\hline Ageratum conyzoides $\mathrm{L}$. & Asteraceae & 7.19 & 10.59 & 0.00 & 6.07 & 5.99 \\
\hline Ajuga bracteosa Wall. Ex Benth & Lamiaceae & 0.00 & 0.00 & 0.00 & 0.00 & 5.14 \\
\hline Anemone vitifolia Buch.-Ham.ex DC & Asteraceae & 0.00 & 0.00 & 0.00 & 3.54 & 0.00 \\
\hline Anaphalis contorta Hook.f. & Asteraceae & 0.00 & 6.36 & 0.00 & 5.58 & 2.78 \\
\hline Apluda mutica $\mathrm{L}$. & Poaceae & 7.89 & 0.00 & 8.65 & 6.55 & 6.57 \\
\hline Argemone mexicana $\mathrm{L}$. & Papaveraceae & 0.00 & 2.83 & 0.00 & 3.06 & 3.36 \\
\hline Arisaema tortuosum (Wall.) Schott & Araceae & 0.00 & 0.00 & 0.00 & 2.04 & 0.00 \\
\hline
\end{tabular}


Artemisia anпua $\mathrm{L}$.

Artemisia nilagirica C.B. Clarke

Arthraxon prionodes (Steud.) Dandy

Begonia picta Smith

Bergenia ciliata (Haw.) Sternb

Boenninghausenia albiflora (Hook.) Rchb. ex Meisn.

Bidens pilosa $\mathrm{L}$.

Bidens biternata (Lour) Sheriff.

Bupleurum tenue Buch.-ham ex D. Don

Cassia occidentalis $\mathrm{L}$.

Carex hirta L.

Cerastium vulgare Hartm.

Clematis buchananiana DC.

Commelina benghalensis L.

Conyza stricta Willd.

Craniotome furcata (Link) Kuntze

Craniotome versicolor Rchb.

Chrysopogon zizanioides (L.) Robert

Cymbalaria muralis G. Gaertn., B. Mey. \& Scherb

Cynodon dactylon (L.) Pers.

Cynoglossum lanceolatum Forssk.

Cyperus rotundus $\mathrm{L}$.

Dicliptera bupleuroides Nees

Dioscorea deltoidea Wall. Ex Griseb.

Erigeron karvinskianus DC.

Eupatorium adenophorum Spreng.

Fagopyrum esculentum Moench.

Fragaria vesca $\mathrm{L}$.

Galinsoga parviflora Cav.

Galium aparine L.

Geranium nepalense Sweet.

Gerbera gossypina (Royle) P. Beauv.

Hedera nepalensis C. Koch

Impatiens bicolour $\mathrm{L}$.

Justicia simplex D. Don

Lepidagathis cristata Willd.

Leucas lanata Benth.

Micromeria biflora (Buch.-Ham. ex D. Don) Benth

Myriactis nepalensis Less.

Oplismenus compositus (L.) P. Beauv.

Oxalis corniculata $\mathrm{L}$.

Persicaria capitata (Buch. Ham. Ex D.Don) H. Gross.

Persicaria nepalensis (Meisner) H. Gross

Persicaria orientalis (L.) Spach

Parietaria officinalis L.

Pennisetum clandestinum Hochst.ex Chiov.

Pimpinella acuminata (Edgew.) C.B. Clarke

Polygonum chinense L.

Potentilla fragarioides $\mathrm{L}$.

Roylea cinerea (D.Don) Baill.

Rubia cordifolia $\mathrm{L}$.

Rumex hastatus D.Don

Salvia officinalis L.

Smilax macrophylla Roxb.

Sigesbeckia orientalis L.

Sonchus oleraceus L.

Strobilanthes angustifrons C.B. Clarke

Thalictrum foliolosum DC.

Trifolium repens $\mathrm{L}$.

Valeriana hardwickii Wall.

Veronica beccabunga $\mathrm{L}$.

Verbascum thapsus L.

Vicia villosa Roth.

Viola canescens Wall. Ex Roxb.

Vitis himalayana (Royle) Brandis

\begin{tabular}{|c|c|c|c|c|c|}
\hline Asteraceae & 0.00 & 0.00 & 0.00 & 0.00 & 5.57 \\
\hline Asteraceae & 0.00 & 0.00 & 0.00 & 6.07 & 0.00 \\
\hline Poaceae & 0.00 & 0.00 & 0.00 & 0.00 & 6.11 \\
\hline Begoniaceae & 0.00 & 0.00 & 0.00 & 2.04 & 0.00 \\
\hline Saxifragaceae & 0.00 & 0.00 & 0.00 & 4.56 & 0.00 \\
\hline Rutaceae & 4.28 & 0.00 & 5.82 & 3.79 & 3.78 \\
\hline Asteraceae & 10.05 & 5.65 & 8.48 & 4.56 & 1.85 \\
\hline Asteraceae & 1.79 & 9.53 & 0.00 & 0.00 & 3.36 \\
\hline Apiaceae & 2.85 & 0.00 & 0.00 & 0.00 & 2.00 \\
\hline Fabaceae & 0.00 & 0.00 & 1.24 & 0.00 & 0.00 \\
\hline Cyperaceae & 0.00 & 4.59 & 0.00 & 0.00 & 0.00 \\
\hline Caryophyllaceae & 0.00 & 0.00 & 0.00 & 0.00 & 2.57 \\
\hline Ranunculaceae & 0.00 & 0.00 & 0.00 & 0.00 & 3.42 \\
\hline Commelinaceae & 8.62 & 8.82 & 8.20 & 6.31 & 4.99 \\
\hline Asteraceae & 0.00 & 0.00 & 0.00 & 8.26 & 4.84 \\
\hline Lamiaceae & 1.79 & 0.00 & 0.00 & 0.00 & 0.00 \\
\hline Lamiaceae & 0.00 & 2.83 & 0.00 & 0.00 & 1.00 \\
\hline Poaceae & 0.00 & 0.00 & 0.00 & 4.47 & 7.87 \\
\hline Plantaginaceae & 0.00 & 0.00 & 7.80 & 0.00 & 5.26 \\
\hline Poaceae & 0.00 & 15.81 & 0.00 & 20.82 & 0.00 \\
\hline Boraginaceae & 0.00 & 0.00 & 0.00 & 3.06 & 0.00 \\
\hline Cyperaceae & 0.00 & 0.00 & 0.00 & 0.00 & 4.05 \\
\hline Acanthaceae & 0.00 & 0.00 & 0.00 & 0.00 & 4.57 \\
\hline Dioscoreaceae & 0.00 & 0.00 & 0.00 & 0.00 & 1.57 \\
\hline Asteraceae & 22.33 & 14.44 & 29.16 & 13.70 & 15.52 \\
\hline Asteraceae & 9.32 & 6.35 & 14.59 & 6.99 & 7.47 \\
\hline Polygonaceae & 5.01 & 6.36 & 0.00 & 0.00 & 0.00 \\
\hline Rosaceae & 5.40 & 0.00 & 7.35 & 0.00 & 7.05 \\
\hline Asteraceae & 5.37 & 0.00 & 0.00 & 0.00 & 3.36 \\
\hline Rubiaceae & 0.00 & 0.00 & 0.00 & 10.64 & 2.42 \\
\hline Asteraceae & 0.00 & 0.00 & 1.53 & 6.02 & 1.57 \\
\hline Asteraceae & 0.00 & 4.95 & 4.86 & 1.26 & 3.57 \\
\hline Araliaceae & 2.85 & 0.00 & 1.24 & 0.00 & 1.00 \\
\hline Balsamiaceae & 6.07 & 1.77 & 4.30 & 0.00 & 2.78 \\
\hline Acanthaceae & 6.85 & 0.00 & 0.00 & 0.00 & 2.57 \\
\hline Acanthaceae & 0.00 & 0.00 & 1.24 & 0.00 & 0.00 \\
\hline Lamiaceae & 1.79 & 2.83 & 3.05 & 0.00 & 0.00 \\
\hline Lamiaceae & 8.98 & 7.06 & 4.01 & 4.07 & 1.21 \\
\hline Asteraceae & 0.00 & 0.00 & 0.00 & 3.54 & 0.00 \\
\hline Poaceae & 7.89 & 26.77 & 11.87 & 8.30 & 4.21 \\
\hline Oxilaceae & 15.14 & 9.86 & 20.46 & 11.71 & 10.29 \\
\hline Polygonaceae & 0.00 & 2.83 & 0.00 & 0.00 & 0.00 \\
\hline Polygonaceae & 0.00 & 8.11 & 10.29 & 8.54 & 5.42 \\
\hline Polygonaceae & 0.00 & 0.00 & 0.00 & 2.04 & 0.00 \\
\hline Urticaceae & 11.86 & 0.00 & 0.00 & 0.00 & 0.00 \\
\hline Poaceae & 3.58 & 0.00 & 4.30 & 7.77 & 9.08 \\
\hline Apiaceae & 2.15 & 0.00 & 2.49 & 0.00 & 2.57 \\
\hline Polygonaceae & 6.44 & 10.22 & 0.00 & 2.72 & 2.00 \\
\hline Rosaceae & 0.00 & 0.00 & 0.00 & 0.00 & 3.21 \\
\hline Lamiaceae & 0.00 & 0.00 & 0.00 & 3.79 & 0.00 \\
\hline Rubiaceae & 0.00 & 0.00 & 0.00 & 0.00 & 2.78 \\
\hline Polygonaceae & 0.00 & 6.36 & 0.00 & 4.07 & 2.36 \\
\hline Lamiaceae & 0.00 & 2.83 & 0.00 & 0.00 & 1.57 \\
\hline Smilaceae & 0.00 & 0.00 & 0.00 & 0.00 & 1.00 \\
\hline Asteraceae & 0.00 & 3.18 & 0.00 & 0.00 & 0.00 \\
\hline Asteraceae & 0.00 & 1.41 & 0.00 & 0.00 & 0.00 \\
\hline Acanthaceae & 7.19 & 6.00 & 4.30 & 1.51 & 2.57 \\
\hline Ranunculaceae & 5.37 & 0.00 & 7.92 & 0.00 & 3.78 \\
\hline Fabaceae & 0.00 & 0.00 & 0.00 & 3.54 & 0.00 \\
\hline Caprifoliaceae & 6.10 & 0.00 & 4.58 & 4.52 & 2.57 \\
\hline Plantaginaceae & 0.00 & 0.00 & 0.00 & 0.00 & 1.00 \\
\hline Scrophulariaceae & 3.58 & 0.00 & 0.00 & 0.00 & 0.00 \\
\hline Fabaceae & 0.00 & 0.00 & 1.24 & 0.00 & 0.00 \\
\hline Violaceae & 7.95 & 0.00 & 8.93 & 4.52 & 4.05 \\
\hline Vitaceae & 4.28 & 6.01 & 2.77 & 0.00 & 2.36 \\
\hline
\end{tabular}


Table 4. Species density of herbs, soil moisture content and total soil nitrogen at five sites in forests of Central Himalaya.

\begin{tabular}{|c|c|c|c|c|c|c|}
\hline \multirow{2}{*}{ Sites } & \multirow{2}{*}{$\begin{array}{l}\text { Species density } \\
\left(\text { Plant } \mathrm{m}^{-2}\right)\end{array}$} & \multicolumn{2}{|c|}{ Soil type } & \multicolumn{2}{|c|}{ Soil moisture (\%) } & \multirow{2}{*}{$\begin{array}{c}\text { Total soil nitrogen } \\
\qquad(\%)\end{array}$} \\
\hline & & $0-15 \mathrm{~cm}$ & $15-30 \mathrm{~cm}$ & $0-15 \mathrm{~cm}$ & $15-30 \mathrm{~cm}$ & \\
\hline RU & 110 & Clay loam & Sandy clay loam & $5.56 \pm 1.83$ & $7.09 \pm 0.75$ & $0.20 \pm 0.04$ \\
\hline $\mathrm{HG}$ & 114 & Clay loam & Sandy clay loam & $7.39 \pm 0.55$ & $9.60 \pm 0.94$ & $0.33 \pm 0.08$ \\
\hline PI & 141 & Sandy clay loam & Sandy clay loam & $6.98 \pm 0.73$ & $9.07 \pm 0.71$ & $0.25 \pm 0.05$ \\
\hline BP & 164 & Clay loam & Sandy clay loam & $11.43 \pm 0.98$ & $15.40 \pm 1.28$ & $0.36 \pm 0.34$ \\
\hline TA & 188 & Sandy loam & Sandy clay loam & $8.03 \pm 1.75$ & $10.75 \pm 1.32$ & $0.41 \pm 0.07$ \\
\hline
\end{tabular}

Table 5. Species diversity and biomass of the herbaceous vegetation at five sites in forests of Central Himalaya.

\begin{tabular}{cccccc}
\hline Sites & $\beta$-diversity & Species number & Shannon's index & Evenness & Biomass $\left(\mathrm{kg} \mathrm{m}^{-2}\right)$ \\
\hline RU & 2.43 & 30 & 4.48 & 1.316 & 5.23 \\
HG & 2.61 & 28 & 4.17 & 1.251 & 3.57 \\
PI & 2.61 & 28 & 4.01 & 1.204 & 2.33 \\
BP & 2.09 & 35 & 4.50 & 1.266 & 6.26 \\
TA & 1.46 & 50 & 5.09 & 1.301 & 6.46 \\
\hline
\end{tabular}

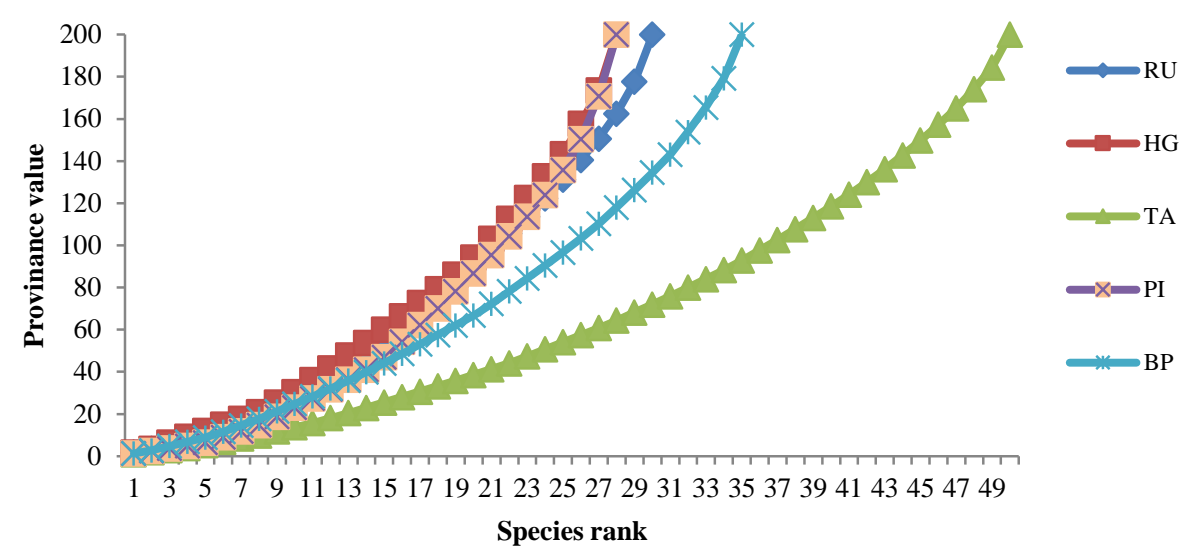

Figure 2. Dominance diversity curve, showing percentage cumulative provenance value plotted against species rank for each site.

Table 6. Index of similarity (\%) between selected forest stands.

\begin{tabular}{cccccc}
\hline & RU & HG & PI & BP & TA \\
\hline RU & 100.0 & 51.72 & 34.48 & 46.15 & 62.50 \\
HG & & 100.0 & 50.00 & 50.79 & 53.84 \\
PI & & 100.0 & 50.70 & 61.53 \\
BP & & & 100.0 & 56.47 \\
TA & & & & 100.0 \\
\hline
\end{tabular}

Table 7. Species turnover (ST) between selected forest stands.

\begin{tabular}{cccccc}
\hline & RU & HG & PI & BP & TA \\
\hline RU & 1.00 & 0.48 & 0.31 & 0.54 & 0.38 \\
HG & & 1.00 & 0.50 & 0.49 & 0.46 \\
PI & & 1.00 & 0.48 & 0.39 \\
BP & & & 1.00 & 0.44 \\
TA & & & & 1.00 \\
\hline
\end{tabular}




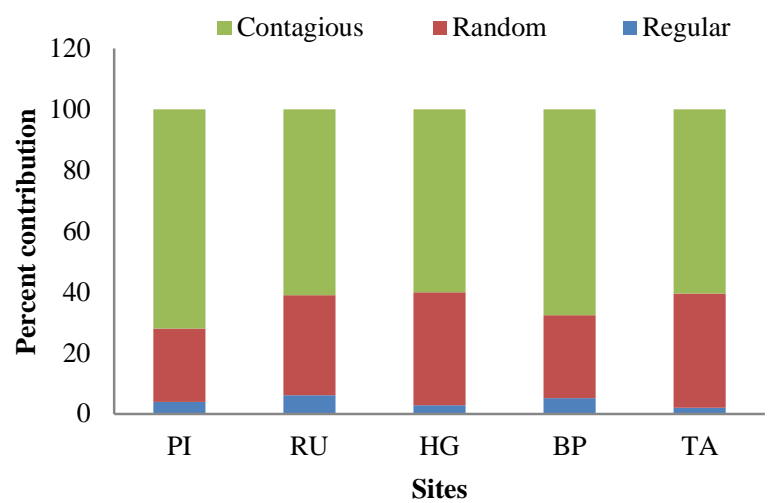

Figure 3. Distribution pattern of herb species at selected forest stands

Table 8. One-way ANOVA for species density (SD), soil moisture (SM) and total soil nitrogen with respect to the selected forest stands

\begin{tabular}{|c|c|c|c|c|c|c|}
\hline \multicolumn{2}{|c|}{ Selected traits } & \multirow[t]{2}{*}{ Sum of Squares } & \multirow[t]{2}{*}{ df } & Mean Square & $\mathrm{F}$ & \multirow{2}{*}{$\begin{array}{c}\text { Significance } \\
\text { level } \\
(\mathrm{P}<0.001) \\
\end{array}$} \\
\hline \multirow{3}{*}{ SD } & Between Groups & & & 6598.800 & - & \\
\hline & Within Groups & 0.000 & 25 & 0.000 & & \\
\hline & Total & 26395.200 & 29 & & & \\
\hline \multirow{3}{*}{ SM } & Between Groups & 144.438 & 4 & 36.109 & 7.973 & 0.000 \\
\hline & Within Groups & 113.228 & 25 & 4.529 & & \\
\hline & Total & 257.666 & 29 & & & \\
\hline \multirow{3}{*}{ TSN } & Between Groups & 0.157 & 4 & 0.039 & 17.627 & 0.000 \\
\hline & Within Groups & 0.056 & 25 & 0.002 & & \\
\hline & Total & 0.212 & 29 & & & \\
\hline
\end{tabular}
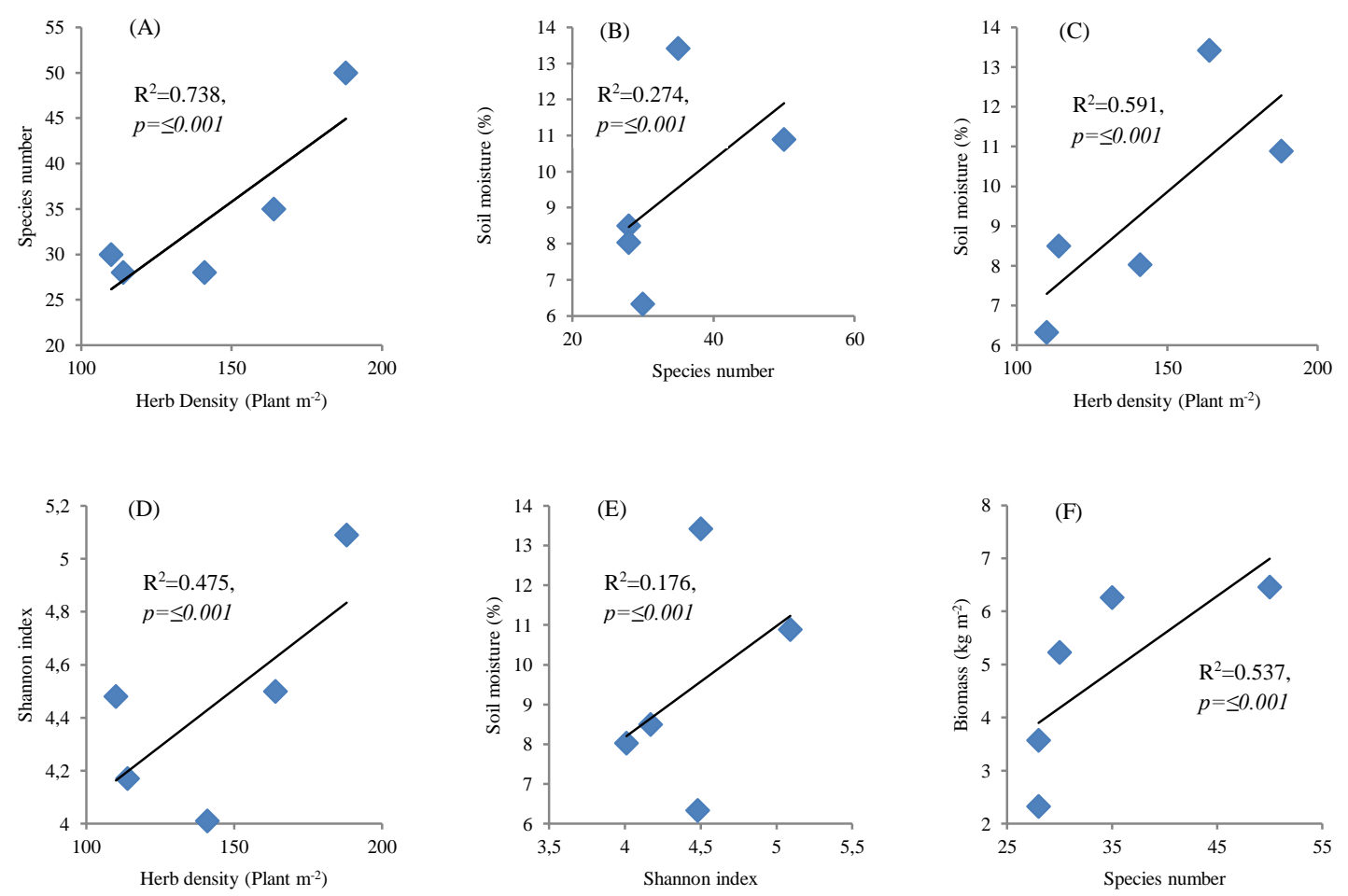

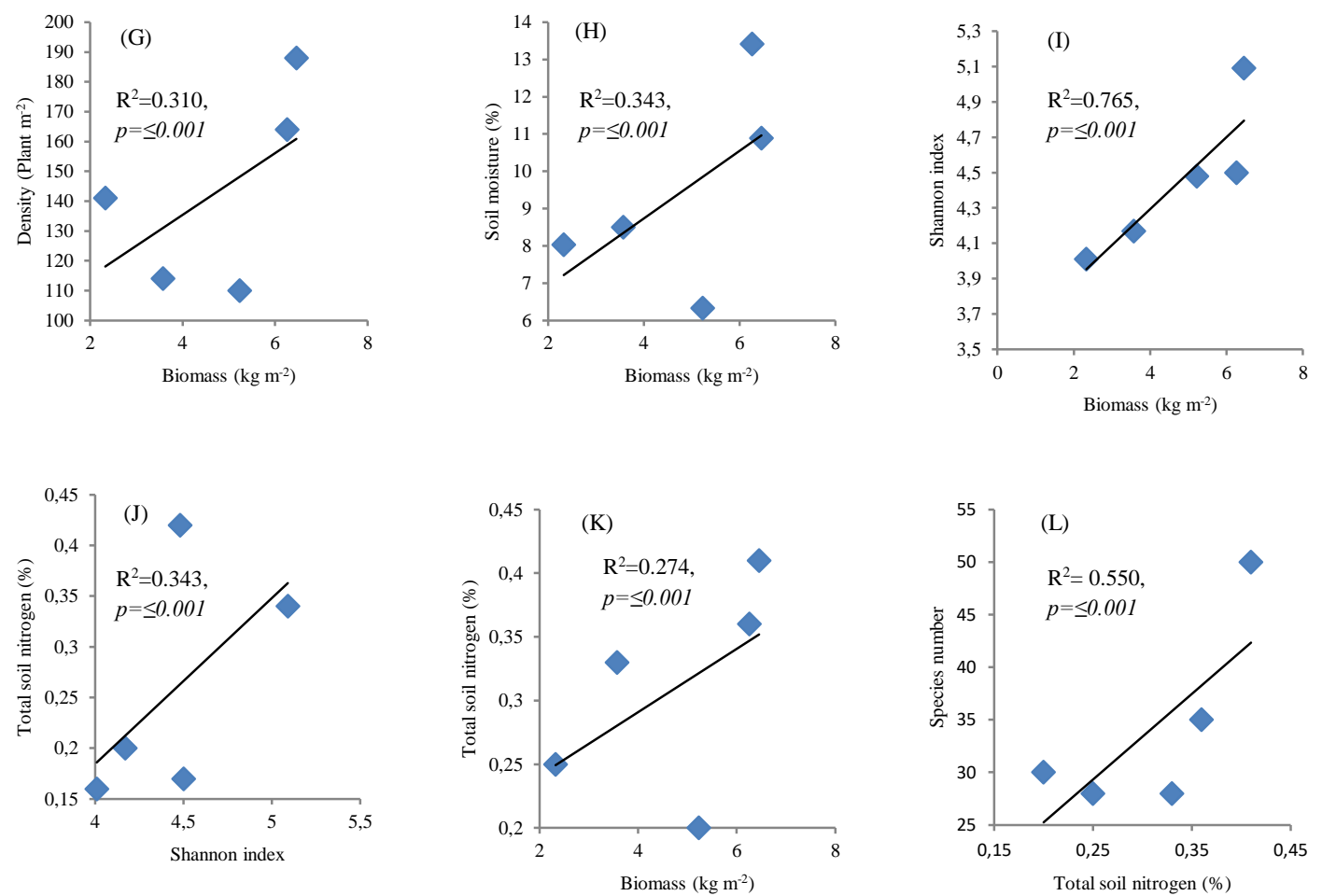

Figure 4. Relationship between different traits of herbs and soil.

Table 9. Relationship of herbaceous biomass with $\alpha$-diversity (Shannon index) and its component (species richness) in Central Himalaya forest, India.

\begin{tabular}{|c|c|c|c|}
\hline Regression models & $R^{2}$ & Standard error of estimate (Sy) & $p$ \\
\hline \multicolumn{4}{|c|}{ Relationships between species richness $(\mathrm{X})$ and biomass $(\mathrm{Y})$} \\
\hline Quadratic & 0.865 & 0.924 & 0.135 \\
\hline Logarithmic & 0.596 & 1.306 & 0.126 \\
\hline Power & 0.509 & 0.350 & 0.176 \\
\hline Linear & 0.538 & 1.397 & 0.159 \\
\hline \multicolumn{4}{|c|}{ Relationships between Shannon index $(\mathrm{X})$ and biomass $(\mathrm{Y})$} \\
\hline Quadratic & 0.964 & 0.481 & 0.036 \\
\hline Logarithmic & 0.794 & 0.932 & 0.042 \\
\hline Power & 0.750 & 0.250 & 0.058 \\
\hline Linear & 0.765 & 0.996 & 0.052 \\
\hline
\end{tabular}

\section{Discussion}

In specific time and space, diversity of vegetation is determined by one of the many abiotic factor soil. Small and McCarthy (2005) showed that biomass, composition and diversity of herbaceous vegetation responded sensitively to change in available soil nitrogen. Soil moisture and soil nitrogen favour growth of annuals or short-lived perennials (Bargali et al. 2015b), the highest soil nitrogen and optimum soil moisture recorded at site-TA resulted in maximum number of species. While at site-PI and HG, comparatively low soil moisture and soil nitrogen decreased species richness possibly due to competition between species for resources.

In this study, the herbaceous vegetation of Central Himalayan forest was identified and then the relationship of those plant species was developed with the soil moisture and nitrogen. Maximum number of herb species was reported at site -TA (50) and minimum number was reported at sites PI and HG (28). In contrast, according to Gilliam (2006) increase in $N$ availability caused loss of many species that are efficient under low $\mathrm{N}$-condition and resulted in decrease in species richness of herbaceous 
vegetation. He proposed $\mathrm{N}$ homogeneity hypothesis, which predicts that the excess $\mathrm{N}$ inputs reduce the naturally high spatial heterogeneity in soil $\mathrm{N}$ availability (i.e. patchiness) that helps to maintain the species diversity of the herbaceous layer, the biodiversity of affected forests will decline (Gilliam, 2006).

Availability of soil moisture and nitrogen in ample amount play very vital role in flourishing herbaceous vegetation and this study showed significant effect of soil moisture and soil nitrogen on herb density as also demonstrated by some researchers (Lv and Dong, 2011; Maestre and Escudero, 2010; Garduno et al. 2010; Legate et al. 2010; Taf et al. 2017). Lowest herb density was recorded at site - RU with lowest percentage of soil moisture and nitrogen (Table 3 ) and maximum herb density was recorded at site- TA with highest soil nitrogen and soil moisture. It has been also recorded in studies demonstrating significant effect between soil moisture and plant diversity (Xu et al. 2015). However, plant community theory assumed interactions between different factors (Grime, 1979; Huston, 1979; Tilman, 1982; Keddy, 1989; Xiong et al. 2003) therefore; many experiments have combined more than two factors to test such effects.

Total density values of herbs in the present study are much higher than the total herb density (15.9-33.3 plant $\mathrm{m}^{-2}$ ) in the mid elevation forest of Central Himalayas, India (Khera et al. 2001) as well total herb density (68-114 plant $\mathrm{m}^{-2}$ ) in the forest stands in the Eastern ghat of India (Behera and Misra, 2006). Maximum species diversity (Shannon-Wiener index) was recorded in the TA forest stand (5.09), which showed maximum species number, may be due to decreased competition and increased resource availability (Sagar et al. 2003). The diversity index values (4.01-5.09) are positively correlated with soil moisture and soil N (Fig. 4). The evenness values ranged between 1.20 (PI) and 1.32 (RU) and showed and an inconsistent pattern with soil moisture and soil N. According to Gillium (2006) decrease in species evenness with increasing soil $\mathrm{N}$ is caused by the increasing dominance of relatively few species that require high $\mathrm{N}$ availability. Studies conducted on the influence of vegetation on soil moisture and suggested that different plant species can affect the temporal and spatial characteristics of the soil moisture in different manner (Zhuang et al. 2015; Musa et al. 2014; Yang et al. 2014; Chen et al. 2007; Zhang et al. 2013) and their distribution also affects the spatial and temporal changes in soil moisture patterns (Wang et al. 2015; Kong et al. 2009; Xu et al. 2015; García-Baquero et al. 2016). Apart from above noteworthy studies, it was determined that soil moisture did not have a significant effect on diversity unless it was part of an interaction with another variable (Xiong et al. 2003), such soil nitrogen of the research site (Smith et al. 2016).

Analysis of PV provides information about social status of a herb species and can be used to recognize the pattern of association of dominant species in a community. Analysis of PV indicated that the three forest stands (PI, RU and TA) represented similar combinations Erigeron karvinskianus (dominant) and Oxalis corniculata (co-dominant) species. The reason that these species grow together is usually because they have similar requirement and their dominance at these sites could be possible due to availability of optimum conditions for their growth. Cynodon dactylon was the dominant species in the $\mathrm{BP}$ forest stand while the co- dominant species (Erigeron karvinskianus) is a common species of the ground vegetation of the natural forest in the area, and was recorded from all the five forest stands. Oplismenus compositus the dominant species in the $\mathrm{HG}$ forest stand is a member of family poaceae and was recorded from all the five forest stands while Cynodon dactylon was the co- dominant species at this site. Therefore, it is concluded that plant species occupied specific climatic and edaphic factors experience variability in their composition.

When the provenance values (PV) of the herbaceous species of the five forest stands were ordinated against the species sequence, the dominant-diversity curves (Whittaker, 1965) followed lognormal distribution in all the stands (Fig. 2). These dominance-diversity curves in the stands indicate the heterogeneity of the species (Bahera and Misra, 2006, Pandey et al. 2018) and suggest that species 
importance is governed by a large number of factors for success in the niche hyperspace (Whittaker, 1970). Higher values of PV in any individual species indicate that all the available resources are being utilized by that species and left over being utilized by other species as the competitor and associates. Similar types of curves have been reported by Sagar et al. (2008a) for the dry-tropical forest in Northern India.

The herbaceous layer significant affect the structure and functioning of forest ecosystems. Though it represents less than $1 \%$ of the biomass of the forest but contain $90 \%$ or more of the plant species of the forest vegetation and contribute up to $20 \%$ of the foliar litter to the forest floor (Gilliam, 2007). The highest herbaceous biomass in the TA forest stand may be attributed to higher diversity and density of herbaceous species. In addition, more moisture and soil nitrogen was available at this site as compared to other sites. Decline in biomass in other forest stands was due to competition among species for the resources, which increased with decrease in resource availability. In this study, herbaceous biomass showed significant positive correlation with species number, density, soil moisture and nitrogen (Fig. $3)$. The herbaceous standing crop biomass reported in this study $\left(2.36-6.46 \mathrm{~kg} \mathrm{~m}^{-2}\right)$ was higher than the values (0.31-0.44 $\mathrm{kg} \mathrm{m}^{-2}$ ) reported for the herbaceous layer of mixed conifer forest in Central Himalaya (Bargali et al. 2015b; Mourya et al. 2019) and $0.008 \mathrm{~kg} \mathrm{~m}^{-2}$ to $0.071 \mathrm{~kg} \mathrm{~m}^{-2}$ reported for the fire affected dry forest ecosystem of Bhoramdeo wildlife sanctuary, India (Jhariya and Singh, 2020a).

Biodiversity is being studied based on species number and evenness (Harper et al. 1994) but diversity is not just based on the number of individuals, but it is also very important that to which species they belong (Peng et al. 2018) because type of species diversity is somewhere directly affected by type of soil characteristics (Migała et al. 2014). In comparison to other studies, smaller differences in soil moisture between sites may be due to shorter (one year) study period. For example, soil moisture data were analysed over 40 years by Song et al. (2013) and monitored soil moisture and temperature were monitored for 3 years by Morecroft et al. (1998). Microclimatic and soil moisture conditions over 6 year period under different gap sizes (canopy cover) were studied by Gray et al. (2002) and a significant effect of gap size on soil moisture and temperature was recorded.

This study demonstrated that the levels of soil moisture and nitrogen significantly affected the patterns of herbaceous floral composition. The individual forest stands harboured 28-50 species, with only nine species being common to all the five forest stands, however, collectively they harboured 73 species. For the management of herbaceous diversity, soil moisture and nutrients can indeed be an important tool. Therefore, it is important to understand how soil moisture impacts plant diversity, because in future climate change will change the soil moisture due to change in pattern of rainfall and increase in temperature. Having a better understanding of how an ecosystem is affected by changes in soil moisture will be helpful to cope with the decreased soil moisture condition. Due to the importance of herbaceous vegetation in forest ecosystems, it is vital that there should be sufficient data that will lead to the proper conservation management.

\section{Acknowledgements}

Authors are thankful to the Head, Department of Botany, D.S.B. Campus, Kumaun University, Nainital for providing necessary facilities and Tea Development Board, Bhowali, Nainital for chemical analysis.

\section{References}

Bargali, K., Joshi, B., Bargali, S.S., Singh, S.P. (2014). Diversity within Oaks. International Oaks, 25:57-70. Bargali, K., Joshi, B., Bargali, S.S., Singh, S.P. (2015a). Oaks and the biodiversity they sustain. International Oaks, 26:65-76.

Bargali, K., Maurya, N.R. Bargali S.S. (2015b). Effect of a Nitrogen-fixing Actinorhizal Shrub on Herbaceous Vegetation in a Mixed Conifer Forest of Central Himalaya. Current World Environment 10(3):957-966.

Bargali, S.S., Bargali, K. (2000). Diversity and biomass of the under story vegetation in an age series of Eucalyptus tereticornis plantation. International Journal of Ecology and Environmental Sciences, 26:173-181. 
Behera, S.K., Misra, M.K. (2006). Aboveground tree biomass in a recovering tropical sal (Shorea robusta Gaertn. f.) forest of Eastern Ghats, India. Biomass and Bioenergy, 30(6):509-521.

Bushing, R.T., Brokaw, N. (2002). Tree species diversity in temperate and tropical forests gaps: the role of lottery recruitment. Folia Geobotanica, 37:33-43.

Chen, L., Huang, Z., Gong, J., Fu, B., Huang, Y. (2007). The effect of land coverage vegetation on soil water dynamic in the hilly area of the loess plateau, China. Catena, 70(2):200-8. https://doi.org/10.1016/j. Catena.2006.08.007

Das, D.K., Chaturvedi, O.P., Mandal, M.P., Kumar, R. (2008). Effect of tree plantation on biomass and primary productivity of herbaceous vegetation in eastern India. Tropical Ecology, 49:95-101.

García-Baquero, G., Silvertown, J., Gowing, D.J., Valle, C.J. (2016). Dissecting the hydrological niche: soil moisture, space and lifespan. Journal of Vegetation Science, 27:219-226.

Garduño, H.R., Fernald, A.G., Cibils, A.F., VanLeeuwen, D.M. (2010). Response of understory vegetation and soil moisture to infrequent heavy defoliation of chemically thinned juniper woodland. Journal of Arid Environments, 74(2):291-7. https://doi.org/10.1016/j.jaridenv.2009.08.005

Gillet, F., Murisier, B., Buttler, A., Gallandat, J., Gobat, J. (1999). Influence of tree cover on the diversity of herbaceous communities in subalpine wooded pastures. Applied Vegetation Science, 2:47-54.

Gilliam, F.S. (2006). Response of the herbaceous layer of forest ecosystems to excess nitrogen deposition. Journal of Ecology, 94:1176-1191.

Gilliam, F.S. (2007). The ecological significance of the herbaceous layer in temperate forest ecosystems. BioScience, 5:7845-7858.

Gray, A.N., Spies, T.A., Easter, M.J. (2002). Microclimatic and soil moisture responses to gapformation in coastal Douglas-fir forests. Canadian Journal of Forest Research, 32:332-343.

Grime, J.P. (1979). Plant Strategies and Vegetation Processes. Wiley, New York.

Harper, J.L., Hawksworth, D.L. (1994). Biodiversity: measurement and estimation. Preface. Philosophical Transactions of the Royal Society of London. Series B: Biological Sciences, 345:5-12.

Huston, M. (1979). A general hypothesis of species diversity. American Naturalist, 113:81-101.

Jhariya, M.K., Bargali, S.S., Swamy, S.L., Oraon, P.R. (2013). Herbaceous diversity in proposed mining area of Rowghat in Narayanpur District of Chhattisgarh, India. Journal of Plant Development Sciences, 5(4):385-393.

Jhariya, M.K., Singh, L. (2020). Herbaceous diversity and biomass under different fire regimes in a seasonally dry forest ecosystem. Environment, Development and Sustainability, 22:1-19.

Karki, H., Rana, P., Bargali, K., Bargali S.S. Rawat Y.S. (2016). Effect of Biotic Disturbances on Herbaceous Vegetation in Cypress Mixed Oak Forests of Central Himalaya, India. Current World Environment 11(2):413422.

Keddy, P.A. (1989). Competition. Chapman \& Hall, New York.

Kershaw, K.A. (1973). Quantitative and dynamic plant ecology. Edward Arnold Ltd. London 308.

Khan, N., Jhariya, M.K. Yadav, D.K., Banerjee, A. (2020a). Herbaceous dynamics and $\mathrm{CO}_{2}$ mitigation in an urban setup-A case study from Chhattishgarh, India. Environmental Science and Pollution Research, 27(3):2881-2897. http://doi.org/10.1007/s11356-019-07182-8.

Khan, N., Jhariya, M.K., Yadav, D.K., Banerjee. (2020b). Structure, diversity and ecological function of shrub species in an urban setup of Sarguja, Chhattishgarh, India. Environmental Science and Pollution Research, 27(5):5418-5432. http://doi.org/10.1007/s11356-019-07172-w.

Khera, N., Kumar. A., Ram, J., Tewari, A. (2001). Plant biodiversity assessment in relation to disturbances in mid elevational forest of Central Himalaya, India. Tropical Ecology, 42:83-95.

Kong, W., Sun, O.J., Xu, W., Chen, Y. (2009). Changes in vegetation and landscape patterns with altered river water-flow in arid West China. Journal of Arid Environments, 73(3):306-13. https://doi.org/10. 1016/j.jaridenv.2008.10.003

Legates, D.R., Mahmood, R., Levia, D.F., DeLiberty, T.L., Quiring, S.M, Houser, C. (2010). Soil moisture: A central and unifying theme in physical geography. Progress in Physical Geography, 35(1):65-86. https:// doi.org/10.1177/0309133310386514

Lv, P., Dong, Z. (2011). Study of the windbreak effect of shrubs as a function of shrub cover and height. Environmental Earth Sciences, 66(7):1791-5. https://doi.org/10.1007/s12665-011-1402-4

Maestre, F., Escudero, A. (2010). Is the patch size distribution of vegetation a suitable indicator of desertification processes? Ecology, 91(12):3742-5. https://doi.org/10.1890/08-2096.1

Maguire, D.A., Forman, R.T.T. (1983). Herb cover effects on tree seedling patterns in a mature HemlochHardwood Forest. Ecology, 64:1367-1380.

Migała, K., Wojtuń, B., Szymański, W., Muskała, P. (2014). Soil moisture and temperature. variation under different types of tundra vegetation during the growing season: a case study from the Fuglebekken catchment, SW Spitsbergen. Catena, 116:10-18.

Misra, R. (1968). Ecology Workbook. Oxford and IBH Publishing Company. Calcutta. 
Montaña, C., Cavagnaro, B., Briones, O. (1995). Soil water use by co-existing shrubs and grasses in the Southern Chihuahuan Desert, Mexico. Journal of Arid Environments, 31:1-13.

Morecroft, M.D., Taylo, R.M.E., Oliver, H.R. (1998). Air and soil microclimates of deciduous woodland compared to an open site. Agricultural and Forest Meteorology, 90:141-156.

Mourya, N.R., Bargali, K., Bargali, S.S. (2019). Effect of Coriaria nepalensis Wall. colonization in a mixed conifer forest of Indian Central Himalaya. Journal of Forestry Research 30(1): 305-317. DOI: 10.1007/s11676018-0613-x.

Muller, R.N. (2003). Nutrient relation of the herbaceous layer in deciduous forest ecosystems: In: Gillam, F.S., Roberts, M.R. (eds) The herbaceous layer in forests of Eastern North America. Oxford University Press, New York, pp, 15-37.

Musa, A., Jiang, D., Niu, C. (2014). The applicable density of sand-fixing shrub plantation in Horqin Sand Land of Northeastern China. Ecological Engineering, 64(1):250-4. https://doi.org/10.1016/j.ecoleng. 2013.12.026

Pandey R., Vibhuti, Karki H., Awasthi P., Bargali K., Bargali, S.S. (2018). Effect of Wildfire on Herbaceous Vegetation in Cypress Mixed Oak Forest of Nainital, Kumaun Himalaya, India. Current Trends in Forest Research: CTFR-121. DOI: 10.29011/2638-0013. 100021

Parihaar, R.S., Bargali, K., Bargali, S.S. (2014). Diversity and uses of Ethno-medicinal plants associated with traditional agroforestry systems in Kumaun Himalaya. Indian Journal of Agricultural Sciences, 84(12):1470-1476. Peach, K., Tracey, M.V. (1956). Modern Methods of Plant Analysis. Vol. 1. Springer- Verlag, Berlin, Germany. Peng, Y., Fan, M., Song, J., Cui, T., Li, R. (2018). Assessment of plant species diversity based on hyperspectral indices at a fine scale. Scientific Reports, 8:1-11.

Sagar, R., Raghubanshi, A.S., Singh, J.S. (2003). Tree species composition, dispersion and diversity along a disturbance gradient in dry tropical forest region of India. Forest Ecology \& Management, 186:61-71.

Sagar, R., Raghubanshi, A.S., Singh, J.S. (2008). Comparison of community composition and species diversity of understorey and overstorey tree species in a dry tropical forest of northern India. Journal of Environmental Management, 88:1037-1046.

San Jose, J.J., Farinas, M.R. (1991). Temporal changes in the structure of a Trachypogon savanna protected for 25 years. Acta Ecologica, 12:237-247

Schnitzer, S.A., Carson, W.P. (2001) Tree fall gaps and the maintenance of species diversity in a tropical forest. Ecology, 82:913-919.

Schoomaker, P., Mckee, A. (1988). Species composition and diversity during secondary succession of coniferous forests in the western cascade Mountains of Oregon. Forest science, 34:960-979.

Shannon, C.E., Weaver, W. (1963). The mathematical theory of communication. University of Illinois Press, Urbana, Illinois.

Singh, J.S., Singh, S.P., Gupta, S.R. (2006). Ecology environment and resource conservation. Anamaya Publishers, New Delhi

Small, C.J., McCarthy, B.C. (2005). Relationship of understory diversity to soil nitrogen, topographic variation, and stand age in an eastern oak forest, USA. Forest ecology and management, 217(2-3):229-243.

Smith, N.G., Schuster, M.J. Dukes, J.S. (2016). Rainfall variability and nitrogen additionsynergistically reduce plant diversity in a restored tall grass prairie. Journal of Applied Ecology, 53:579-586.

Smith, R.L. (1974). Ecology and Field Biology. Harper and Row, New York, NY. 850.

Song, Y.T., Zhou, D.W., Zhang, H.X., Li, G.D., Jin, Y.H., Li, Q. (2013). Effects of vegetation height and density on soil temperature variations. Chinese Science Bulletin, 58:907-912.

Taf, D.S., de Andrade, L.A., Freitas, H., Da, S.S.A. (2017). Biological Invasion Influences the Outcome of PlantSoil Feedback in the Invasive Plant Species from the Brazilian Semi-arid. Microbial Ecology, 1-11. https://doi.org/10.1007/s00248-017-0999-6 PMID: 28560606

Tilman, D. (1982). Resource Competition and Community Structure. Princeton University Press, Princeton.

van Swaay, C.A.M. (2002). The importance of calcareous grasslands for butterflies in Europe. Biological Conservation, 104:315-318.

Wang, T., Wedin, D.A., Franz, T.E., Hiller, J. (2015). Effect of vegetation on the temporal stability of soil moisture in grass-stabilized semi-arid sand dunes. Journal of Hydrology, 521: 447-59. https://doi.org/10.1016/j.jhydrol.2014.12.037

Whittaker, R.H. (1972). Evolution and measurement of species diversity. Taxon, 21:213-251.

Whittaker, R.H. (1970). Communities and Ecosystems, Macmillan, New York.

Whittaker, R.H. (1965). Dominance and diversity in land plant communities. Science, 147:250-260.

Xiong, S., Johansson, M.E., Hughes, F.M.R., Hayes, A., Richards, K.S., Nilsson, C., (2003). Interactive effects of soil moisture, vegetation canopy, plant litter and seed addition on plant diversity in a wetland community. Journal of Ecology, 91:976-986.

Xu, X., Zhang, Q., Tan, Z., Li, Y., Wang, X. (2015). Effects of water-table depth and soil moisture on plant biomass, diversity, and distribution at a seasonally flooded wetland of Poyang Lake, China. Chinese Geographical Science, 25:739-756. 
Yang, L., Wei, W., Chen, L., Chen, W., Wang, J. (2014). Response of temporal variation of soil moisture to vegetation restoration in semi-arid Loess Plateau, China. Catena, 115:123-33. https://doi.org/10.1016/j. catena.2013.12.005

Zhang, X.F., Zhao, L., Xu, S.J.Jr., Liu, Y.Z., Liu, H.Y., Cheng, G.D. (2013). Soil moisture effect on bacterial and fungal community in Beilu River (Tibetan Plateau) permafrost soils with different vegetation types. Journal of Applied Microbiology, 114(4):1054-65. https://doi.org/10.1111/jam.12106 PMID: 23241008.

Zhuang, W.W., Serpe, M., Zhang, Y.M. (2015). The effect of lichen-dominated biological soil crusts on growth and physiological characteristics of three plant species in a temperate desert of northwest China. Plant Biology (Stuttgart, Germany), 17(6):1165-75. https://doi.org/10.1111/plb.12359 PMID: 26084731.

Submitted: 16.12 .2020

Accepted: 08.03.2020 